Paedagogia Christiana

I/29 (2012) - ISSN 1505-6872

\title{
Bogusław Milerski, Hermeneutyka pedagogiczna. Perspektywy pedagogiki religii, Wydawnictwo Naukowe ChAT, Warszawa 2011, ss. 335 .
}

Do prowadzonej w polskich środowiskach katechetyczno-pedagogicznych dyskusji nad specyfiką pedagogiki religii wpisuje się pozycja Hermeneutyka pedagogiczna. Perspektywy pedagogiki religii autorstwa ks. Bogusława Milerskiego, duchownego Kościoła ewangelicko-augsburskiego, znawcy zarówno niemieckojęzycznej, jak i anglosaskiej literatury, podejmującej problemy pedagogiki religii. Sama publikacja została przedstawiona jako tak zwana „książka habilitacyjna” w UAM w Poznaniu.

Autor publikacji opartej na filozoficzno-teologicznych podstawach chrześcijańskiej antropologii przedstawia własne rozwiązania dotyczące edukacji, w tym także edukacji religijnej. Wskazuje przy tym na potrzebę badań nad powiązaniami nauk filozoficzno-teologicznych z naukami humanistycznymi i na odwrót. Swe stanowisko uzasadnia tym, że ,jednym z najistotniejszy wyzwań współczesności, przed którym stoi zarówno jednostka, jaki i całe społeczeństwa, w tym także Kościoły, jest problem ustanowienia harmonii pomiędzy zachowaniem tożsamości, zakorzenionej w tradycji, a otwarciem się na świat i dokonujące się w nim przemiany". Wychodząc przy tym z założenia, iż religia nie może przeszkadzać człowiekowi w jego rozwoju, wskazuje na możliwości odwoływania się do religii w procesach edukacji oraz na możliwe skutki tego rodzaju działań.

Efektem prowadzonych przez ks. B. Milerskiego badań jest przedstawiona propozycja koncepcji pedagogiki religii. W koncepcji tej ujmuje wychowanie religijne nie tyle w kategoriach osiągania konkretnych kompetencji technicznych, lecz jako możliwość nabywania przez wychowanka umiejętności interpretowania rzeczywistości, w jakiej przychodzi mu żyć. Wraz z tymi propozycjami przedstawia podstawy hermeneutyki pedagogicznej, 
stanowiącej ważny składnik teorii kształcenia humanistycznego i religijnego. Efekty tych badań przedstawił w „książce habilitacyjnej”: Hermeneutyka pedagogiczna. Perspektywy pedagogiki religii. Sposób prowadzenia badań autor rozprawy zaprezentował we wstępie do publikacji (s. 21-22).

W oparciu o wypracowane pojęcie ,hermeneutyki pedagogicznej”, którą nazywa „,pedagogiczną teorią rozumienia i interpretacji uprawianą na gruncie tradycji, określonej przez zakres merytoryczny przyjętej wykładni hermeneutyki” (s. 131) twierdzi, że „hermeneutyka pedagogiczna dotyka kwestii fundamentalnej, a mianowicie rozumienia i interpretacji jako podstawy badania rzeczywistości wychowawczej, sposobu poznania w procesie kształcenia i samego procesu kształtowania jednostkowego bytu" (s. 133).

W zrozumieniu myśli autora pomocne jest zwrócenie uwagi na znaczenie nadawane używanemu w publikacji pojęciu „rozumienie”. Ks. Milerski rozumie pod nim świadome odnoszenie się bytu ludzkiego do sposobów możliwości własnego życia (bytowania) w świecie oraz refleksyjny proces nadawania znaczeń egzystencjalnych poprzez identyfikację i interioryzację sensów. Jego zdaniem znaczenie tego pojęcia jest różne od innych pojęć epistemologicznych, takich jak „myślenie”, „rozumowanie” czy „poznanie” (s. 208). Według niego „rozumienie” jako egzystencjalny akt podmiotu nie jest abstrakcyjne, lecz zawsze jest wypełnione treścią. Samo rozumienie prowadzi do podejmowania działań związanych z interpretacją rzeczywistości. To z kolei prowadzi do odkrywania istniejących reguł określających jego poprawność bądź wiarygodność (s. 136).

Rozwijaną w toku badań teorię hermeneutyki pedagogicznej przenosi na płaszczyznę pedagogiki religii. Wyraża przy tym nadzieję, że dostarczy ona inspiracji współczesnej hermeneutyce pedagogicznej do tworzenia podstaw koncepcji kształcenia ogólnego - humanistycznego oraz religijnego. Co się zaś tyczy samego kształcenia religijnego, to jest przekonany, że religia dla całościowo ujętego procesu kształcenia powinna stanowić podstawy refleksji nad ludzką egzystencją. Jego zdaniem, „refleksyjność” występująca w procesach edukacji prowadzi wychowanka do podmiotowego, afirmacyjnego i krytycznego przetwarzania podawanych mu treści oraz uczy odnosić je do swej egzystencji, a nie tylko ich poznawczego odwzorowywania. Przestrzega przy tym przed zawężaniem wychowania do religii, do kształcenia wprowadzającego w określoną religię. Zasadność tej przestrogi wyjaśnia tym, że kształcenie religijne jest czymś szerszym aniżeli wychowanie do religii, gdyż odnosi się do całości problematyki wychowawczej. Dlatego, jego zdaniem, mówiąc o kształceniu religijnym winno się mieć na uwadze działania zmierzające do rozwijania kompetencji mentalnych, szczególnie rozumienia oraz krytycznego myślenia. Nadto należy zwracać uwagę na rozwijanie kompetencji dotyczących ludzkiej egzystencji i jej społeczno-kulturowego 
kontekstu. Uważa też, że miarą tak rozumianego kształcenia religijnego nie mogą być wyuczone zachowania, gesty czy słowa, lecz sposób rozumiejącego postrzegania siebie i świata w odniesieniu do tradycji i religii.

W rozumieniu ks. B. Milerskiego wypracowana teoria kształcenia w pedagogice religii ma nie tyle opisywać całość procesów edukacji religijnej, co skupiać się na ich podstawach. Habilitant uważa też, że „hermeneutyka pedagogiczna dotyka kwestii fundamentalnej, a mianowicie rozumienia i interpretacji jako podstawy badania rzeczywistości wychowawczej, sposobu poznania w procesie kształcenia i samego procesu kształtowania jednostkowego bytu" (s. 133). Posługując się tym tokiem rozumowania, Habilitant stwierdza, że „z perspektywy istotnościowego związku pomiędzy rozumieniem i kształceniem można hermeneutycznie analizować sam proces kształcenia".

Wypracowaną przez ks. B. Milerskiego koncepcję kształcenia należy uznać za ważny element rozwijanej teorii kształcenia zarówno humanistycznego, jak i religijnego. Koncepcja hermeneutyki pedagogicznej jest pedagogiczną teorią rozumienia i interpretacji sensów i wartości obecnych w wytworach kulturowych, w ekspresjach i zachowaniach ludzkich. Sama teoria rozumienia i interpretacji zasadniczo odnosi się do zagadnień humanistycznej metodologii badań pedagogicznych. Charakteryzuje ją odróżnianie katechetyki od pedagogiki religii, a w konsekwencji katechezy od wychowania religijnego. $\mathrm{W}$ rozumieniu autora omawianej publikacji podstawą tego rozróżnienia jest uznanie autonomii i równości badań teologicznych i humanistycznych w zakresie życia religijnego.

Znaczącą trudnością, jaką napotkał autor publikacji przy prowadzeniu swych badań, okazało się samo rozumienie pedagogiki religii. Uznał, że pod tym pojęciem zawiera się dyscyplina „współczesnej humanistyki i nowocześnie rozumianej teologii, która wykorzystuje hermeneutyczną perspektywę do popisu rzeczywistości wychowawczej" (s. 207). Przy tej okazji przypomniał, że pojęcie to znane jest od dziesiątków lat przede wszystkim w środowiskach kultury niemieckojęzycznej i anglosaskiej, znacznie krócej w tradycji polskiej. Zwrócił też uwagę na to, że nie jest ono przez wszystkich autorów jednoznacznie definiowane. Ukazując różne ujmowanie pedagogiki religii zdefiniował ją jako tę dyscyplinę nauki, która zajmuje się zagadnieniami praktyki i teorii szeroko pojętych procesów edukacji i socjalizacji religijnej. Pedagogikę religii uważa za dyscyplinę ,naukową badającą edukacyjny potencjał różnych postaci religii i formułującą teorię kształcenia religijnego i socjalizacji religijnej w obszarze Kościoła, rodziny, szkoły i społeczeństwa" (s. 138).

Jasność terminologiczna, a nadto przytaczane argumenty zaczerpnięte z bogactwa myśli filozoficzno-teologicznej oraz pedagogicznej wielu zna- 
czących autorów powodują, że publikacja winna zostać zauważona i brana pod uwagę w dalszej dyskusji nad istotą pedagogiki religii i konsekwentnie wychowania religijnego.

Zbigniew Marek*

\section{Jarosław Michalski, Sens życia a pedagogika. Impulsy myśli Viktora E. Frankla, Wydawnictwo Naukowe UMK, Toruń 2011, ss. 300.}

Lektura prac ks. dr. hab. Jarosława Michalskiego, prof. UMK, przekonuje, że niemal od początku naukowej drogi przejawiał on wrażliwość na taki sposób opisywania człowieka, który ukazuje go jako poszukującego prawdy i sensu sprzyjających życiu. Temu nachyleniu refleksji nad wychowaniem człowieka ks. J. Michalski dał wyraz między innymi w pracy habilitacyjnej Edukacja i religia jako źródła rozwoju egzystencjalno-kognitywnego. Studium hermeneutyczno krytyczne (2004). Zdaniem J. Michalskiego, studia nad człowiekiem nie znajdują uzasadnienia, jeśli nie dotyczą ujęcia całościowego, wspierającego sens życia (zob. s. 14). W powyższej pracy podkreślał „ciągłą niezbędność tworzenia sensu” (tamże, s. 15).

Do pytania o sens powrócił w najnowszej publikacji Sens życia a pedagogika. Impulsy myśli Viktora E. Frankla (2011). Uczynił to w sposób bardziej zasadniczy niż w pracy poprzedniej, gdzie zagadnienie sensu było motywem mniej istotnym dla podejmowanego tam pytania badawczego.

W książce, która jest przedmiotem niniejszej recenzji, ks. J. Michalski podejmuje próbę zwrócenia uwagi na istotność powiązań pedagogiki z pytaniem o sens, który autor ujmuje jako doświadczenie egzystencjalne, a nie jako czynność intelektualną. Polem jego szczególnego zainteresowania badawczego stała się egzystencjalna koncepcja człowieka V. E. Frankla, stojąca w opozycji do biologistycznego, redukcjonistycznego i reifikującego traktowania człowieka podczas jego egzystencji.

Recenzowana praca składa się z wprowadzenia, dwu części, zakończenia, bibliografii oraz obcojęzycznego streszczenia. Została wydana przez Wydawnictwo Naukowe Uniwersytetu Mikołaja Kopernika w Toruniu. Liczy 300 stronic. Recenzje wydawnicze napisali: prof. dr hab. Józef Binnebesel i ks. prof. dr hab. Mirosław Kalinowski.

* Ks. prof. dr hab. Zbigniew Marek SJ - profesor zwyczajny w Instytucie Nauk o Wychowaniu Akademii Ignatianum w Krakowie. 